NBER WORKING PAPER SERIES

\title{
THE USE OF REPLACEMENT WORKERS \\ IN UNION CONTRACT NEGOTIATIONS: \\ THE U.S. EXPERIENCE, 1980-1989
}

Peter C. Cramton

Joseph S. Tracy

Working Paper No. 5106

\author{
NATIONAL BUREAU OF ECONOMIC RESEARCH \\ 1050 Massachusetts Avenue \\ Cambridge, MA 02138 \\ May 1995
}

Funding has been provided by National Science Foundation grant SBR-9122707. We thank the Bureau of National Affairs for providing us with wage and strike information. We thank workshop participants at the Department of Justice, University of North Carolina, University of Maryland, University of Pittsburgh, and U.S. Census Bureau for their helpful comments. This paper is part of NBER's research program in Labor Studies. Any opinions expressed are those of the authors and not those of the National Bureau of Economic Research.

() 1995 by Peter C. Cramton and Joseph S. Tracy. All rights reserved. Short sections of ext, not to exceed two paragraphs, may be quoted without explicit permission provided that full credit, including () notice, is given to the source. 


\title{
THE USE OF REPLACEMENT WORKERS \\ IN UNION CONTRACT NEGOTIATIONS: \\ THE U.S. EXPERIENCE, 1980-1989
}

\begin{abstract}
It is argued in many circles that a structural change occurred in U.S. collective bargaining in the 1980s. We investigate the extent to which the hiring of replacement workers can account for this change. For a sample of over 300 major strikes since 1980, we estimate the likelihood of replacements being hired. We find that the risk of replacement declines during tight labor markets, and is lower for bargaining units with more experienced workers. We use the predicted replacement risk as an explanatory variable in a model of the union's choice between the strike and holdout threat. We find that strike usage decreases significantly as the predicted replacement risk increases. We estimate that a ban on the use of replacement workers would have increased strike incidence from $1982-1989$ by 3 percentage points, a 30 percent increase.
\end{abstract}

Peter C. Cramton

Department of Economics

University of Maryland

College Park, MD 20742-7211
Joseph S. Tracy

Department of Economics

Columbia University

International Affairs Building

420 West 118 th Street

New York, NY 10027

and NBER 
It is widely believed that U.S. collective bargaining has changed substantially in the 1980 s from earlier decades. ${ }^{1}$ One piece of evidence used to support this view is that strike activity as measured by the Bureau of Labor Statistics (BLS) declined by over $50 \%$ from its level in the $1970 \mathrm{~s}$. Less well known is that this decline was the result of a shift in the composition of labor disputes, not a decline in overall dispute activity. Cramton and Tracy (1992) demonstrate that a sharp increase occurred in the percentage of labor disputes that are settled without a strike under an extension of the expired contract (a "holdout").

The reason for this composition shift has yet to be empirically established. Labor leaders argue that this change in collective bargaining tactics has been necessitated by the increased tendency for firms to hire replacement workers if the union calls a strike. Organized labor has lobbied for several years for Congress to "restore the strike threat" by amending the labor law to ban the use of permanent replacements. ${ }^{2}$ Careful consideration of such legislation is hampered by the lack of any comprehensive analysis of the use of replacement workers in the U.S.

In this paper, we present a detailed description of the determinants of the firm's decision to hire replacement workers during a strike. We show that the replacement risk facing a union varies systematically with the work experience of its members and the tightness of the local labor market. We use this systematic variation in replacement risk to measure its impact on the union's threat choice between strike and holdout. We find that increases in the predicted replacement risk significantly increases the likelihood that the union selects the holdout threat. An implication of our estimates is that if a ban on replacement workers had been in effect during the 1980 s, strike incidence would have increased by 3 percentage points, a 30 percent increase. However, a potential mitigating effect of a ban on replacements is the possibility of reduced incidence of violence during contract negotiations.

The outline of the paper is as follows. In section 1 we summarize our earlier efforts at establishing that the shift in collective bargaining patterns represents a change in the process of

${ }^{1}$ See Cappelli $(1982)$, Freedman $(1982,1985)$, and Mitchell $(1982,1983)$ for related discussions.

${ }^{2}$ The first bill was introduced into Congress in 1988 by Representative Brennan which proposed banning the use of permanent replacements during the initial ten weeks of a strike. A strengthened version of this bill was introduced into the 101 st Congress (H.R. 3936 \& S. 2112) which proposed completely banning the use of permanent replacements. In 1992, similar legislation passed in the House but failed in the Senate. In 1993, the replacement bill was reintroduced (H.R. 5 \& S. 55). On 8 March 1995, President Clinton signed an executive order banning the federal government from doing business with firms that use permanent replacements. 
bargaining. In section 2 we summarize the existing empirical literature on replacement workers. In section 3 we discuss our data collection efforts and present an overview of the use of replacement workers in the 1980s. In section 4 we present a simple model of the firm's decision to use replacements. Our empirical implementation of this model is given in section 5. Specifically, we provide an analysis of the determinants of the replacement hiring decision by the firm, and its impact on the threat choice decision by the union. We evaluate the economic significance of our findings, and compare them to estimated replacements effects from Canadian data. The paper ends with a summary of our findings.

\section{A Perspective on Collective Bargaining in the 1980s}

The 1980s proved to be a difficult decade for the U.S. labor movement. The private sector unionization rate fell into single digits leaving many to wonder if unions would soon become an anachronism. Unions like politicians are typically measured by the general populace in terms of their impact on the pocketbook. The changing economic and political landscape in the 1980s may have seriously imperiled the ability of unions to produce visible benefits for their members. ${ }^{3}$

Many of the benefits of unionization are embodied in the labor contracts they negotiate. The process of labor contract negotiations, then, is vital to the institutional interests of unions. An examination of the collective bargaining process in the 1980s reveals significant changes from the 1970s. Cramton and Tracy (1992) emphasize that unions have multiple threat options available when a labor contract expires. The union can either call a strike or extend the former contract, a holdout. In a holdout, the union applies pressure on the firm through a work-to-rule, slow-down, or other "in plant" strategies. Figure 1 illustrates that the incidence of strikes fell in the 1980 s while the incidence of holdouts rose sharply.

An explanation for this shift in the composition of labor disputes has not been demonstrated to date. Labor leaders attribute the shift to the growing risk of union workers being replaced in the event of a strike. ${ }^{4}$ In 1981, President Reagan replaced the air traffic controllers after their union, PATCO,

${ }^{3}$ See Farber and Krueger (1992) for an analysis of changing worker attitudes toward unions.

${ }^{4}$ The right of firms to hire replacement workers during an economic strike was upheld by the Supreme Court in its 1938 decision Mackay Radio \& Telegraph Co. v. NLRB (304 U.S. 333). Once the strike is settled, the firm must restrict its future hiring from within the bargaining unit. 


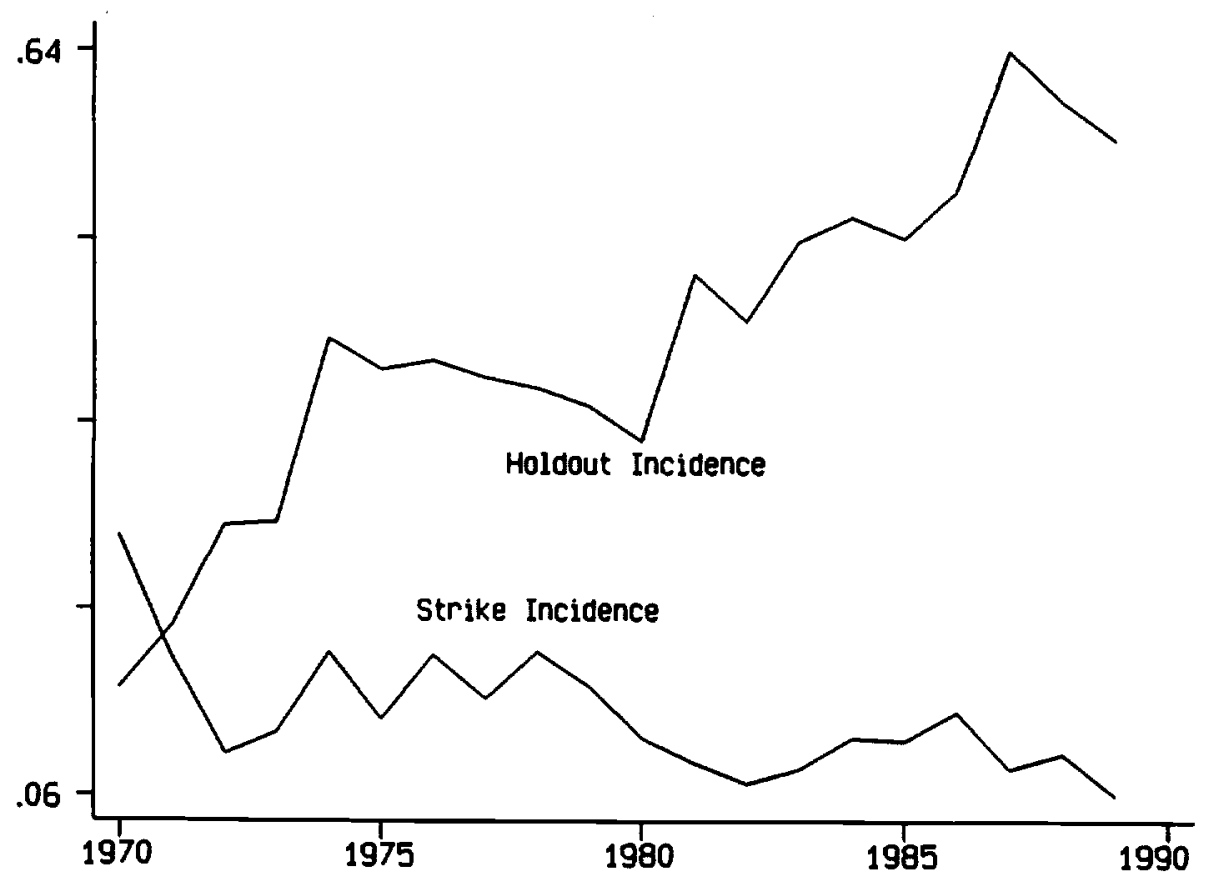

Figure 1. 
called an illegal strike. As a result of the President's action, the union was decertified. ${ }^{5}$ Unions claim that this dramatic action signaled to the private sector that hiring replacements is both legal and acceptable. The Industrial Union Department of the AFL-CIO in a 1986 manual for its union leaders titled The Inside Game: Winning With Workplace Strategies argues that the threat of replacement has significantly diminished the attractiveness of the strike threat relative to the holdout threat:

To be sure, the strike in many cases is still a powerful and effective weapon. But when an employer begins trying to play by the "new rules" and actually force a strike, staying on the job and working from the inside may be more appropriate (page 5, emphasis in original).

Whether the 1980s represent a structural break in the process of collective bargaining is addressed in Cramton and Tracy (1994). In this paper, we estimate the first empirical model of the determinants of labor disputes, and the composition of these disputes between strikes and holdouts. The observed changes in the patterns of strike and holdout incidence illustrated in Figure 1 could be the result of changes in the economic environment, rather than the result of changes in the collective bargaining process itself. Using data on twelve hundred major contracts negotiated between 1970 and 1989, we find mixed evidence supporting the structural change hypothesis.

Without controlling for any covariates, the fraction of disputes involving a strike is 13 percentage points lower in the post-1981 period, a significant difference. When we control for the covariates suggested by our bargaining model (Cramton and Tracy 1992), this difference falls to 7.5 percentage points and is only marginally significant. Replacing the post-1981 indicator with eight year indicators, we find that the year effects are jointly insignificant and that 1989 is the only individually significant year effect.

To test for the stability of our estimated bargaining model over the two decade period, we interact the post-1981 indicator with each variable in our empirical model. The chi-square statistic (probability value) for the joint significance of the intercept and slope interactions is $26.1(0.02)$, and for the slope interactions alone is $23.4(0.02)$. The interactions with the industry employment residual and the real wage change over the prior contract were both individually significant. In contrast to the evidence regarding a shift in the overall composition of disputes, there is clearer evidence that the responsiveness of the union's threat choice to underlying economic variables has shifted since 1981 .

${ }^{5}$ On 12 August 1993, President Clinton lifted the ban on hiring former PATCO members that had participated in the strike. 
The key interaction from the viewpoint of the theory is with the real wage change over the prior contract. Our bargaining model predicts that the attractiveness of the strike threat decreases as the real wage at the end of the prior contract increases. This suggests a negative coefficient on the real wage change over the prior contract in predicting the likelihood of a strike given a labor dispute. The data indicate an increase in the marginal effect associated with the real wage change of 13 percentage points between the pre- and the post-1981 period, a statistically significant change. This increase is sufficient to reverse a negative and significant coefficient on the real wage change for the 1970-81 period to a positive and marginally significant coefficient for the $1982-89$ period.

This shift in the response of the union's threat choice to key economic factors could reflect an increasing threat of replacement in the 1980s. We will show below that the use of replacement workers is strongly associated with concession bargaining. Firms demanding nominal wage concessions are much more likely to use replacement workers in the event of a strike. To the extent that these concessions begin to manifest themselves through real wage declines during the prior contract, then a growing use of replacements would be expected to shift the coefficient on the real wage variable in the dispute composition model. Direct testing of this hypothesis requires data on the use of replacement workers.

\section{Summary of Replacement Worker Literature}

There are only a handful of papers that analyze data on the use of replacement workers in U.S. contract negotiations. This reflects the difficulty in obtaining replacement data. The Government Accounting Office (GAO 1991) undertook a study of the use of replacements at the request of the Senate Subcommittee on Labor which was considering replacement legislation. The GAO obtained data from the Federal Mediation and Conciliation Service (FMCS) on all strikes in 1985 and $1989 .^{6}$ They surveyed the firm and union involved in all major strikes (those involving at least 1,000 workers) and a random sample of the smaller strikes. From this data, the GAO reports that $11 \%$ $(17 \%)$ of major (smaller) strikes in 1985 involved replacements, and 9\% (16\%) involved replacements in 1989. The GAO also reports that the occurrence of replacements was three times higher in strikes which lasted at least a month in duration.

${ }^{6}$ Only bargaining units covered by the NLRA are required to file with the FMCS before a strike. As a result, the GAO sample excludes negotiations in the trucking and airline industries, which are covered by the Railway Labor Act. 
Olson (1991) reports on the use of replacements in major U.S. strikes between 1984-1988, and in New York strikes for three periods before the Wagner Act. For the 1980s, Olson finds that the incidence of replacements is $10.5 \%$. For the earlier periods, Olson finds that the use of replacements ranged from a low of $1.5 \%$ in $1926-31$ to a high of $61 \%$ in $1881-86$. Like the GAO report, Olson also finds that the use of replacements is associated with longer strike duration. Interpreting this correlation is difficult, however, without information on the timing of the hiring of the replacements. The finding is consistent with the hazard rate from strike to settlement being higher, lower, or unchanged following the hiring of replacements.

Based on a sample of thirty-five large strikes in the U.S. and twenty-one small strikes in New York from 1984 to 1988, Gramm (1991) reconfirms that strike durations are much longer when permanent replacements are hired. Gramm reports that permanent replacements were hired in $20 \%$ of her strikes and temporary replacements in $8 \%$. Gramm's data also includes information on the firm's operating capacity during the strike. In the U.S. sample, the mean operating capacity was $57 \%$ with no replacements, $90 \%$ with temporary replacements, and $77 \%$ with permanent replacements. In the New York sample, the mean operating capacity was around $60 \%$ regardless of the use of replacements.

Gramm and Schnell (1993) extend Gramm's earlier work. They find that firms hiring permanent replacement workers have a higher operating capacity even after controlling for other factors which may affect the firm's operating effectiveness. The percentage of strikers who are reinstated following the settlement of a strike is significantly lower for strikes involving permanent replacements. Finally, they report that firms hiring permanent replacements conclude the negotiations on average with more favorable terms. ${ }^{7}$

\section{Collection of Replacement Data}

Over the past two years we have carried out an extensive project to collect data on the use of replacement workers during contract negotiations in the 1980s. We restricted our collection efforts to strikes involving bargaining units with at least 1,000 workers. In principal, these major strikes can be matched up with collective bargaining chronologies compiled by the BLS that we have analyzed in

${ }^{7}$ This finding is sensitive to how the authors treat not reaching a contract. The positive effect of hiring replacements occurs when not reaching a contract is treated as the most favorable outcome to the firm. When the authors delete the negotiations that fail to reach a contract, then permanent replacements yield on average less favorable terms to the firm. 
our earlier studies. Using previously collected strike information, we conducted computer literature searches for each strike in our sample using the Lexis/Nexis service. ${ }^{8}$ This service provides coverage of most major newspapers, magazines and trade journals since the early 1980s, and all National Labor Relations Board and U.S. Federal Court cases since 1972.

We combined our strike information with the summaries from the literature searches to form a profile for each strike in our sample occurring during the 1980s. As a further check, we surveyed each of the firms and unions involved in these strikes. To this end, we developed a contact data base listing the appropriate firm and union representatives, addresses, and phone numbers. Phone contacts were made in each case to verify this information. The survey requested corrections and/or additions to the information in our strike profile, and included several questions that solicit further background information. The response rate after a follow up request was approximately $15 \%{ }^{9}$ The analysis in this paper uses the combined BLS, BNA, Lexis/Nexis, and survey data.

We have data on 316 major strikes in the 1980s that can be linked to the BLS bargaining chronologies. The incidence of permanent replacement workers is $7.9 \%$, while the incidence of temporary replacements is $8.9 \%$. These figures match up closely with the earlier findings. Table 1 illustrates that the likelihood of replacements being hired during a strike varies across years. While there is considerable variation in these figures due to the small number of major strikes in a given year, this variation suggests that the decision to use replacements may depend on underlying macro and labor market conditions. Table 2 illustrates that risk of replacement also varies across industry classifications. Again, the impression is that the decision to use replacements may depend on product market conditions, capital structure, and characteristics of workers in each industry. Together, these two tables suggest that the risk of replacement is unlikely to be uniform across bargaining units and time periods, but rather may follow systematic patterns. Identifying these patterns will point to negotiations in the 1980s where the replacement risk remained low, and consequently strikes should have remained a viable union threat choice.

Our data allow us to paint a general picture of the bargaining environment where replacements are hired. Wages are the primary issue in roughly $64 \%$ of the major strikes in the 1980 s. The onset

${ }^{8}$ The strike information is gathered from BLS and Bureau of National Affairs (BNA) reports. This data is available through ICPSR by referencing Cramton and Tracy (1992).

${ }^{9}$ We attribute part of this low response to the long time lag between the strikes in question and our survey date. In many cases, the company was reorganized or the relevant parties were no longer with the firm or union. We expect that surveying contemporaneous negotiations would result in a higher yield. 
Table 1: Incidence of Replacements, by Year.

\begin{tabular}{|c|c|c|}
\hline Year & $\begin{array}{l}\text { Number of } \\
\text { Strikes }\end{array}$ & $\begin{array}{c}\text { Number of } \\
\text { Replacements }\end{array}$ \\
\hline 1980 & 41 & $\begin{array}{c}2 \\
(4.8)\end{array}$ \\
\hline 1981 & 30 & $\begin{array}{c}2 \\
(6.7)\end{array}$ \\
\hline 1982 & 23 & $\begin{array}{c}2 \\
(8.7)\end{array}$ \\
\hline 1983 & 33 & $\begin{array}{c}7 \\
(21.2)\end{array}$ \\
\hline 1984 & 37 & $\begin{array}{c}9 \\
(24.3)\end{array}$ \\
\hline 1985 & 33 & $\begin{array}{c}5 \\
(15.2)\end{array}$ \\
\hline 1986 & 44 & $\begin{array}{c}6 \\
(13.6)\end{array}$ \\
\hline 1987 & 19 & $\begin{array}{c}4 \\
(21.0)\end{array}$ \\
\hline 1988 & 21 & $\begin{array}{c}4 \\
(19.1)\end{array}$ \\
\hline 1989 & 19 & $\begin{array}{c}4 \\
(21.1)\end{array}$ \\
\hline
\end{tabular}

Notes: Cell counts (row percents). 
Table 2: Incidence of Replacements, by Industry

\begin{tabular}{|c|c|c|}
\hline CPS Industry & $\begin{array}{l}\text { Number of } \\
\text { Strikes }\end{array}$ & $\begin{array}{l}\text { Number of } \\
\text { Replacements }\end{array}$ \\
\hline Primary Metals & 14 & $\begin{array}{c}1 \\
(7.1)\end{array}$ \\
\hline Fabricated Metals & 16 & $\begin{array}{c}0 \\
(0.0)\end{array}$ \\
\hline Machinery, except Electrical & 26 & $\begin{array}{c}1 \\
(3.9)\end{array}$ \\
\hline Electrical Equipment & 14 & $\begin{array}{c}1 \\
(7.2)\end{array}$ \\
\hline Trans Equip - Automobiles & 16 & $\begin{array}{c}0 \\
(0.0)\end{array}$ \\
\hline Trans Equip - Aircraft & 16 & $\begin{array}{c}4 \\
(25.0)\end{array}$ \\
\hline Trans Equip - Other & 14 & $\begin{array}{c}3 \\
(21.4)\end{array}$ \\
\hline Food & 21 & $\begin{array}{c}5 \\
(23.8)\end{array}$ \\
\hline Paper & 15 & $\begin{array}{c}3 \\
(20.0)\end{array}$ \\
\hline Other Trans & 20 & $\begin{array}{c}7 \\
(35.0)\end{array}$ \\
\hline Communications & 16 & $\begin{array}{c}2 \\
(12.5)\end{array}$ \\
\hline Other Public Utilities & 21 & $\begin{array}{c}2 \\
(9.5)\end{array}$ \\
\hline Other Retail Trade & 20 & $\begin{array}{c}9 \\
(45.0)\end{array}$ \\
\hline Medical, except Hospitals & 19 & $\begin{array}{c}6 \\
(31.6) \\
\end{array}$ \\
\hline
\end{tabular}

Notes: Cell counts (row percents) given for industries with at least 10 strikes in the sample period. 
of concession bargaining is evidenced by the fact that $14 \%$ of strikes where wages were the primary issue involved demands by the firm for nominal wage reductions. Importantly, though, strikes where replacements were hired account for $32 \%$ of these wage reduction cases, more than twice the share of replacements in overall strikes. Further, the use of permanent replacements is often preceded by layoffs during the prior contract, and involves violence during the negotiations. When replacements are hired, on average $36 \%$ (permanent) and $41 \%$ (temporary) of the bargaining unit is replaced. The firm's operating capacity during a strike is higher on average when the firm hires replacements. The mean operating capacity figures in our sample are $43 \%$ when no replacements are hired, $67 \%$ when temporary replacements are hired, and $56 \%$ when permanent replacements are hired.

Earlier studies consistently find longer strike durations associated with the hiring of replacements. Not surprisingly, our data illustrate the same association. The mean strike duration in our sample is 32 days if no replacements are hired, 70 days if temporary replacements are hired, and 217 days if permanent replacements are hired. A further understanding of this effect requires information on the timing of the onset of hiring of replacements. The mean number of days between the prior contract expiration and the hiring of replacements in our data is 12 days for temporary replacements and 48 days for permanent replacements. Comparing these figures suggests that the impact of replacements is to reduce the hazard rate from strike to settlement. However, one must be careful in interpreting this finding, since many of the longest "strikes" are actually situations where the union workforce has been replaced and the contract negotiations have effectively ceased. ${ }^{10}$

\section{Incorporating Replacements Into a Bargaining Model}

In this section, we provide a brief sketch of how the replacement decision can be added to the basic wage bargaining model in Cramton and Tracy (1992). Our purpose is to show how the threat of temporary replacement affects the union's decision to strike. We find that as the risk of replacement increases the strike threat becomes less attractive to the union. Strike incidence, then, should drop with a greater risk of replacement.

We begin by summarizing our earlier model. The union and firm are bargaining over the wage $w$ to be paid during a contract. The union is uncertain about the firm's willingness to pay $v$. Bargaining begins with the union selecting a threat $\theta \in\{H, S\}$, either holdout or strike, which applies until a

\footnotetext{
${ }^{10}$ Firms hiring permanent replacements have an incentive to prolong a strike. Replaced striking workers retain their voting rights for a period of twelve months following the start of the strike (Landrum Griffin amendments to the Wagner Act, 1959).
} 
settlement is reached. In the holdout threat, the union workers puts pressure on the firm while continuing to work under the terms of the expired contract. In the strike threat, the union workers withhold their labor services. There is some inefficiency associated with disagreement in either threat. Inefficiencies arise in the holdout threat through union tactics such as work-to-rule and sickouts. In the threat $\theta$, the payoff to the union is $x_{\theta}$ and the payoff to the firm is $a_{\theta} v-b_{\theta}$, where $a_{\theta} \in[0,1)$ and $b_{\theta} \geq 0$. The term $1-a_{\theta}$, which we call the dispute cost, measures how far the parties are from the Pareto frontier during the threat $\theta$. Since the total payoff in agreement is $v$ and the total payoff in the threat is $a_{\theta} v-b_{\theta}+x_{\theta}$, the inefficiency from disagreement is $\left(1-a_{\theta}\right) v+b_{\theta}-x_{\theta}=\left(1-a_{\theta}\right)\left(v+c_{\theta}\right)$, where $c_{\theta}=\left(b_{\theta}-x_{\theta}\right) /\left(1-a_{\theta}\right)$. This inefficiency is the pie that can be gained through settlement.

An outcome of the bargaining, denoted $\langle t, w, \theta\rangle$, specifies the time of agreement $t$, the contract wage $w$ at the time of agreement, and the threat $\theta \in\{H, S\}$ before agreement. We assume that the union and firm are risk neutral and that the payoff flows, both during the threat and after agreement, are constant over time. The overall payoffs, then, are calculated as a combination of the threat payoff and the agreement payoff, weighted by the fraction of time spent in each outcome.

After the union's threat choice, the union and firm alternate wage offers, with the union making the initial offer. After an offer is made, the other side has two possible responses: (1) a counteroffer, in which case the bargaining continues, or (2) acceptance, in which case the bargaining ends with labor supplied at the offered wage for the remainder of the contracting period. As in Admati and Perry (1987), a bargainer can delay responding to an offer. This assumption leads to the signaling equilibrium in which the firm signals its value through its willingness to delay agreement. For simplicity, we assume that the minimum time between offers is arbitrarily small.

The equilibrium takes a simple form. If the wage $w_{0}$ under the expired contract is sufficiently low (below an indifference level $\tilde{w}$ ) the union decides to strike; otherwise ( $w_{0} \geq \tilde{w}$ ) the union decides to hold out. The indifference level $\tilde{w}$ depends on the threat payoffs and the distribution of $v$. A second indifference level $m$ is determined by the union's initial offer. The firm accepts the union's initial offer if its valuation is above $m$ and otherwise rejects the offer. If the firm rejects the offer, it waits until it has credibly signalled its valuation before making an acceptable counteroffer. The counteroffer is the full-information wage offer, which in the case of equal discount rates is given by $w_{\theta}(v)=x_{\theta}+$ $1 / 2\left(1-a_{\theta}\right)\left(v+c_{\theta}\right)$. The union gets its threat payoff, $x_{\theta}$, plus one-half of the inefficiency avoided by settlement, $\left(1-a_{\theta}\right)\left(v+c_{\theta}\right)$. 
We modify this game by allowing the firm to decide to replace the workforce. If the union selects the strike threat and the firm finds the union's initial offer unacceptable, then the firm decides whether to replace the workforce at a cost $c$. Replacement can be thought of as a new threat $\theta=R$ with its own threat payoffs. The cost $c$ represents the hiring and training costs associated with replacement. It is assumed that the replacements' productivity is some fraction $a_{R}<1$ of the productivity of the prior workers.

To understand the implications of this model, first consider the case where $v$ and $c$ are known by the firm and the union. The full-information settlement wages under the three threats, $w_{H}(v), w_{S}(v)$, and $w_{R}(v)$, play an essential role in determining the outcome. If the cost of replacement is prohibitively high or the replacement wage is higher than the strike wage, $w_{R}(v) \geq w_{S}(v)$, then the firm never hires replacements. The settlement wage in this case is the strike wage $w_{S}(v)$ or the holdout wage $w_{H}(v)$, whichever is greater. Now suppose that the replacement wage is less than the strike wage, $w_{R}(v)<w_{S}(v)$. This wage differential gives the firm an incentive to replace if the cost of replacement is not too high. In the event that the union selects the strike threat, it will reduce its wage demand in order to keep the firm from hiring replacements. The union offers the wage $w \leq w_{S}(v)$, such that the firm is indifferent between accepting $w$ or replacing the workforce and settling at $w_{R}(v)$. As a result, we never observe replacements used, but the threat of replacement reduces the union's wage demand in the strike threat.

Now suppose that $v$ is again common knowledge, but the firm has private information about the cost $c$ of replacement. In particular, suppose the cost of replacement is either low or high, $c \in\{\ell, h\}$, and let $p=\operatorname{Pr}(c=\ell)$ be the probability of a low replacement cost. Assume $w_{R}(v)<w_{S}(v)$, so that the firm has an incentive to use replacements. Also assume that $h$ is sufficiently low that the high-cost firm $(c=h)$ prefers to replace and pay the replacement wage, rather than settle at the strike wage. Hence, the union must be concerned about replacement by both types of firms. There are two possible equilibria, pooling and separating.

Pooling equilibrium. If $\ell$ and $h$ are close, the union will make a pooling offer that both firm types accept: the union offers the wage $w_{\ell}$ that makes the low-cost firm $(c=\ell)$ indifferent between accepting and replacing (the high-cost firm strictly prefers to accept). The union successfully avoids replacement by offering a sufficiently low wage. The strike threat is made less attractive by the possibility of replacement, because the union reduces its strike demand to avoid replacement.

Separating equilibrium. As the gap between $\ell$ and $h$ widens, it becomes increasingly costly for the union to prevent the low-cost firm from replacing. At some point, the equilibrium switches from 
the pooling equilibrium (without replacement) to a separating equilibrium in which the union offers the wage $w_{h}$ that makes the high-cost firm indifferent between accepting and replacing. The low-cost firm strictly prefers to replace in this case. In this equilibrium, the probability of replacement is just $p$ $=\operatorname{Pr}(c=\ell)$ and the union reduces its offer $w_{h}$ to keep the high-cost firm from replacing. The expected wage is $p w_{R}(v)+(1-p) w_{h}$. Since $w_{h}>w_{R}(v)$, the expected wage if the union selects the strike threat falls as the risk of replacement increases. But since the union only strikes if the expected strike wage exceeds the holdout wage, this implies that the union becomes less likely to select the strike threat as the risk of replacement increases.

The intuition is clear. A firm considers the replacement option because it improves the firm's threat payoff relative to the union's, resulting in a lower wage. However, the firm must balance this improvement in the terms of trade with the cost of replacement. A firm only uses replacements if its cost of replacement is sufficiently low. The union, anticipating the possibility of replacement, lowers its wage demand in the strike threat in order to reduce the probability of replacement. This risk of replacement, then, reduces the attractiveness of the strike threat, making it more likely that the union adopts the holdout threat at the outset of negotiations.

With full-information about $v$, settlement occurs immediately. Hence, to be consistent with the data, we need to introduce private information about $v$ as well as $c$. This need not upset the equilibrium above. The intuition is essentially the same, but now disputes may take time to settle. For a wide range of parameters we get the following equilibrium. The firm surely replaces if its cost of replacement is $\ell$ and never replaces if its cost of replacement is $h$. In this case replacement signals the cost of replacement, but does not signal anything about $v$. Since replacement is a sunk cost, the signaling of this cost does not play a strategic role. The fraction of strikes involving replacements depends almost entirely on the probability of a low cost of replacement. Empirically, this probability may depend on economic variables such as the local rate of unemployment, or on industry factors such as changes in production technology. In deciding whether to strike or holdout, the union estimates this probability of replacement. If it is too great, the union selects the holdout threat.

\section{The Firm's Decision to Replace and its Consequences for the Union's Threat Choice}

The summaries given in Tables 1 and 2 suggest that the replacement risk facing a union if it selects the strike threat may vary systematically with some underlying economic factors. Our bargaining model indicates that a union's perceived replacement risk is a key parameter in its choice 
between the strike and the holdout threat. We assume that unions form their expectations regarding this replacement risk by examining the characteristics of bargaining situations in which replacements were used. Systematic patterns that emerge can be used by a union to inform itself of its own replacement risk.

The firm's decision to replace is based on weighing the wage reductions that can be gained by using replacements versus the cost of hiring replacements and any resulting loss in productivity. Our model considered a simplified version in which the firm faces either high or low replacement costs. All firms with low replacement costs find it in their interest to replace workers on strike, while all firms with high replacement costs do not find it in their interest to hire replacements.

The union's search for patterns in the replacement data should begin with variables that potentially relate to the firm's cost of using replacements. For example, the more the firm engages in specific training of its workers the more reticent the firm will be to lose this investment through hiring replacements, and the more difficult it will be for the firm to find adequately skilled replacements. The decision to hire replacements must also be cast with an eye toward the ability of the firm to quickly find replacement workers. This suggests that conditions in the labor market (local and possibly industry) may be important. Tight labor markets will increase the cost of replacements by driving up the spot wage, or increasing the time required to replace a given fraction of the bargaining unit.

To begin to identify the underlying determinants of the replacement decision, we have collected data on many of the variables relevant to the firm's cost of replacements. Our first effort is to attempt to proxy for differing levels of specific human capital investments across our bargaining units. We currently do not observe any demographic information on the workers in our bargaining units. This may be possible in the future through continued direct surveying of the bargaining units. For now, we use only the industry affiliation of the bargaining unit.

We created extracts of union workers using Current Population Survey (CPS) data for the period 1980-1991. We sorted these workers into major CPS industry/year cells, calculated means of their potential labor market experience, and then smoothed these averages across years using weighted linear regression. We linked these smoothed data series into our collective bargaining file based on the bargaining unit's SIC classification and the expiration year of the prior contract.

Variations in labor market experience will help to capture differences in training investments occurring at the extensive margin. Holding experience constant, differential investment levels across bargaining units can arise at the intensive margin due to differences in the rate of job training. We use 
two different approaches in an attempt to capture this additional source of variation. Industries which on average invest in a higher rate of job training per year should have steeper wage/experience profiles. ${ }^{11}$ To measure these differential returns to experience we created extracts of nonunion workers using CPS surveys for the period 1980-1991. We estimated simple wage equations by major CPS industry. We do not attempt to measure any time variation in these returns to experience, and focus instead on industry differences. ${ }^{12}$

Our second measure of differences is a proxy for differences in technological progress by industry. The variable we use is the industry employment share of scientists and engineers, a measure proposed by Allen (1992). Bartel and Sicherman (1994) find that increases in this employment share are associated with a significant increase in hours of company training among workers in the National Longitudinal Survey of Youth data. They found similar effects when productivity growth or computer investment measures were used in place of the employment share

To study the impact of labor market conditions on the replacement decision, we use measures developed for our earlier studies. Specifically, we measure aggregate labor market conditions using the prime-age male unemployment rate aggregated to a quarterly basis. For industry and local labor market conditions we fit regression models to the BLS quarterly unadjusted employment series from 1970 to 1989 allowing for quadratic trends, quarterly seasonal effects, and autoregressive error terms.

$$
\begin{aligned}
\ln E_{i t} & =\beta_{i o}+\beta_{i 1} t+\beta_{i 2} t^{2}+\sum_{j=1}^{3} \delta_{i j} Q_{j}+U_{i t} \\
U_{i t} & =\phi(L) U_{i t-1}+\epsilon_{i t},
\end{aligned}
$$

where $\ln E_{i t}=\log$ quarterly employment in industry $i$ at time $t ; Q_{j}=$ dummy variable for the $j$ th quarter; $\phi(L)=$ second-order distributed lag polynomial; and $\epsilon_{i t}=$ white noise error term. We

\footnotetext{
${ }^{11}$ We assume here that firms and workers have an incentive to share in the costs and returns of specific training in order to minimize turnover.

${ }^{12}$ We control for a worker's education, experience, marital status, sex and race. We constructed a similar series of return estimates using the extract of union workers. The process of collective bargaining may introduce several other considerations that affect the wage/experience slopes in union contracts. For this reason, we prefer the nonunion estimates.
} 
measure the tightness of the labor market using the quarterly employment residual, $\hat{U}_{i t}$, for the quarter in which the prior contract expired. ${ }^{13}$

The structure of collective bargaining in the industry may also have an impact on the firm's replacement decision. The industrial relations literature has long emphasized that the bargaining power of unions depends crucially on the concentration of union membership in an industry. For example, the ability of unions to use bargaining tactics such as pattern bargaining is greatly weakened when the union membership becomes fragmented across several unions.

For each industry, a union coverage concentration measure is constructed from the bargaining unit coverage numbers in our data and BLS industry employment data. We observe the size of every bargaining unit at the outset of each contract it negotiates. We interpolate between contracts to construct a bargaining unit coverage history. For each month, we aggregate across bargaining units in a given industry to estimate the total industry coverage. Annual averages of industry coverage levels are normalized by BLS employment rates to arrive at the industry/year coverage rate ${ }^{14}$ Since the union is identified in our data, we can measure the concentration of the union coverage in an industry across different unions. We calculate by industry and year a Herfindahl index of union coverage concentration.

We consider two additional variables that may affect the firms decision to use replacements. Holding constant the local labor market conditions, the ability of a firm to hire replacements may depend on local union sentiments. If unions enjoy wide public support in a locality, there will be even greater social pressure exerted on workers not to cross picket lines. To capture geographic variation in this union sentiment, we include an indicator variable for whether collective bargaining is prohibited for state public sector workers.

The final variable we consider is an indicator for whether "similar" bargaining units experienced replacements in a recent contract negotiation. Unions that observe replacements being used at similar bargaining units will likely revise upward their assessment of their own replacement risk. We define similar to mean a bargaining unit in the same two-digit industry classification and state. We restrict attention to negotiations that occurred within a year prior to the contract expiration. Specifically, we code an indicator which takes a value of one if a bargaining unit in the same industry and state

\footnotetext{
${ }^{13}$ Positive residuals correspond to tighter employment conditions.

${ }^{14}$ See also Bronars, Deere, and Tracy (1993) for a discussion of constructing firm level unionization measures from this contract data.
} 
experienced replacements during contract negotiations that occurred within the prior twelve months of the contract expiration.

Summary statistics on our strike sample disaggregated by the firm's replacement decision are provided in Table 3a. While our data classifies replacements as temporary or permanent, we ignore this distinction for the rest of our analysis. There are several reasons for this decision. The classification of replacements is based on an ex post analysis of the strike. At the time that the firm makes a replacement decision, it is typically unclear if the replacements will be temporary or permanent. Workers that are hired as temporary can be converted to permanent status, while permanent replacements are sometimes dismissed following the end of a strike. ${ }^{15}$ It seems reasonable that the union's primary concern is whether the firm will choose to use replacements.

In order to calculate estimates of replacement risks for bargaining units in our sample, we first estimate a probit model of the firm's replacement decision. Table 4 presents the implied marginal effects of our variables on the probability that the firm uses replacements given that the firm exercises the strike threat. These marginal effects have been standardized to represent the effect of a one standard deviation (unit) change in a continuous (indicator) variable on the replacement risk. Our baseline model is given in specification (1). Increasing years of work experience significantly lowers the risk of replacement. A one standard deviation increase in average experience (2.2 years), reduces replacement risk by over 8 percentage points, nearly 70 percent of the sample standard deviation in the replacement indicator.

The other statistically significant finding is that the risk of replacement is lower when local labor markets are tighter. A one standard deviation increase in the state employment residual is associated with over a 4 percentage point reduction in replacement risk. The effect of tightness in the industry labor market is in the same direction, but is much smaller in magnitude.

Bargaining units in industries with more concentrated union coverage face lower replacement risk. The magnitude of this effect, however, is small and not precisely measured. Similarly, bargaining units in states which prohibit collective bargaining by their state public sector workers face a slightly higher replacement risk. Again, this effect is small in magnitude and not statistically significant. Finally, the largest effect in the data is associated with the prior replacement indicator. Bargaining units observing this prior replacement usage face over a 12 percentage point increase in

\footnotetext{
${ }^{15}$ The case law provides some restrictions on the process used by the firm to classify replacements as temporary or permanent. Permanent replacements who are later dismissed, may also have grounds for suing for damages, see Belknap v. Hale, 463 U.S. 491 (1983).
} 
Table 3: Descriptive Statistics

\begin{tabular}{|c|c|c|c|c|c|c|}
\hline \multirow[b]{2}{*}{ Variable } & \multicolumn{2}{|c|}{ Overall } & \multicolumn{2}{|c|}{ No Replacements } & \multicolumn{2}{|c|}{ Replacements } \\
\hline & Mean & Std Dev & Mean & Std Dev & Mean & Std Dev \\
\hline Replacement indicator & 0.134 & 0.341 & & & & \\
\hline Experience & 22.1 & 2.2 & 22.4 & 2.0 & 20.4 & 2.8 \\
\hline $\begin{array}{l}\text { Nonunion returns to } \\
\text { experience }\end{array}$ & 0.007 & 0.002 & 0.007 & 0.002 & 0.006 & 0.002 \\
\hline $\begin{array}{l}\text { Scientist \& engineer } \\
\text { employment share }\end{array}$ & 0.050 & 0.037 & 0.052 & 0.036 & 0.034 & 0.039 \\
\hline $\begin{array}{l}\text { State employment } \\
\text { residual }\end{array}$ & -0.007 & 0.035 & -0.005 & 0.036 & -0.017 & 0.028 \\
\hline $\begin{array}{l}\text { Industry employment } \\
\text { residual }\end{array}$ & -0.011 & 0.077 & -0.009 & 0.080 & -0.023 & 0.054 \\
\hline $\begin{array}{l}\text { Union coverage } \\
\text { concentration }\end{array}$ & 0.565 & 0.246 & 0.566 & 0.244 & 0.556 & 0.257 \\
\hline $\begin{array}{l}\text { Prior replacement } \\
\text { useage }\end{array}$ & 0.020 & 0.139 & 0.018 & 0.134 & 0.029 & 0.171 \\
\hline $\begin{array}{l}\text { Collective bargaining } \\
\text { prohibited for state } \\
\text { workers }\end{array}$ & 0.098 & 0.298 & 0.100 & 0.300 & 0.088 & 0.288 \\
\hline
\end{tabular}


Table 3: Descriptive Statistics, Continued

(b) Dispute Sample, 1982-1989

\begin{tabular}{|c|c|c|c|c|c|c|}
\hline \multirow[b]{2}{*}{ Variable } & \multicolumn{2}{|c|}{ Overall } & \multicolumn{2}{|c|}{ No Strike } & \multicolumn{2}{|c|}{ Strike } \\
\hline & Mean & Std Dev & Mean & Std Dev & Mean & Std Dev \\
\hline Strike Indicator & 0.176 & 0.381 & & & & \\
\hline Unemployment rate & 6.24 & 1.52 & 6.24 & 1.52 & 6.24 & 1.52 \\
\hline $\begin{array}{l}\text { State employment } \\
\text { residual }\end{array}$ & -0.017 & 0.031 & -0.016 & 0.030 & -0.021 & 0.031 \\
\hline State employment trend & 0.005 & 0.002 & 0.005 & 0.002 & 0.005 & 0.002 \\
\hline $\begin{array}{l}\text { Industry employment } \\
\text { residual }\end{array}$ & -0.019 & 0.071 & -0.017 & 0.071 & -0.027 & 0.073 \\
\hline $\begin{array}{l}\text { Industry employment } \\
\text { trend }\end{array}$ & -0.001 & 0.005 & -0.001 & 0.006 & -0.001 & 0.005 \\
\hline Union coverage density & 0.232 & 0.214 & 0.223 & 0.205 & 0.275 & 0.248 \\
\hline $\begin{array}{l}\text { Union coverage } \\
\text { concentration }\end{array}$ & 0.616 & 0.234 & 0.621 & 0.232 & 0.593 & 0.243 \\
\hline $\begin{array}{l}\% \text { change in real wage } \\
\text { over prior contract }\end{array}$ & -0.012 & 0.066 & -0.013 & 0.067 & -0.001 & 0.059 \\
\hline $\begin{array}{l}\text { Predicted replacement } \\
\text { risk }\end{array}$ & 0.119 & 0.119 & 0.121 & 0.125 & 0.114 & 0.090 \\
\hline
\end{tabular}


Table 4: Probit Model of Replacement Risk

\begin{tabular}{lccc}
\hline \hline Variable & $(1)$ & $(2)$ & $(3)$ \\
\hline Experience & -0.083 & -0.079 & -0.075 \\
& $(0.018)$ & $(0.020)$ & $(0.021)$ \\
Experience x nonunion & & -0.008 & \\
returns to experience & & $(0.021)$ & \\
Experience x scientist \& engineer & & & -0.016 \\
employment share & & & $(0.023)$ \\
State employment residual & -0.042 & -0.042 & -0.043 \\
& $(0.022)$ & $(0.022)$ & $(0.022)$ \\
Industry employment residual & -0.015 & -0.015 & -0.013 \\
& $(0.023)$ & $(0.023)$ & $(0.024)$ \\
Union coverage concentration & -0.018 & -0.019 & -0.018 \\
& $(0.020)$ & $(0.020)$ & $(0.020)$ \\
Prior replacement useage & 0.123 & 0.139 & 0.148 \\
& $(0.186)$ & $(0.198)$ & $(0.199)$ \\
Collective bargaining & 0.019 & 0.018 & 0.020 \\
prohibited for state workers & $(0.077)$ & $(0.077)$ & $(0.078)$ \\
Log likelihood & -86.31 & -86.23 & -86.07 \\
Number of observations & 254 & 254 & 254 \\
\hline
\end{tabular}

Notes: Coefficients represent the marginal effect of a one standard deviation (unit) change in a continuous (indicator) variable on the replacement probability. Standard errors are given in parentheses. 
their replacement risk, a standard deviation change in the replacement indicator. While likely important, this variable is imprecisely measured.

In specification (2), we allow the effect of experience to vary with the nonunion returns to experience. The data indicate that an additional year of experience lowers the risk of replacement differentially more in industries with higher rates of return to experience. Similarly, in specification (3), we allow the effect of experience to vary with the employment share of scientists and engineers. Again, the data indicate that an additional year of experience reduces replacement risk differentially more in industries in which technological progress is likely to be more prevalent. However, the evidence on the importance of the intensive margin is weak at best given the lack of significance of both of these interactions.

Using specification (1) from Table 4, we predict the probability of replacement for all labor disputes in our sample for which the underlying variables are available. A kernel density estimate of the distribution of the overall replacement risk is presented in Figure 2. Summary statistics on this distribution is provided in Table 5 . Consistent with the earlier summary tables, the predicted replacement risk varies widely over bargaining units in our sample. At the extremes, some bargaining units face virtually no risk of replacement, while others face a risk approaching 75 percent. We next use this variation in an attempt to measure the impact of replacement risk on the union's threat choice.

If the threat of replacements causes unions to shift from the strike to the holdout threat, we would expect to see a negative coefficient on the predicted replacement risk in a threat-choice model. To check this, we estimate a probit model of the probability that the union selects the strike threat given that a labor dispute occurs. Table $3 \mathrm{~b}$ provides summary statistics for this sample. Table 6 presents the marginal effects based on the probit coefficients.

Specification (1) estimates a baseline model using disputes from 1982 to $1989 .{ }^{16}$ This specification is based on our previous work (Cramton and Tracy 1994). Specification (2) incorporates the estimated replacement risk displayed in Figure 2. A one standard deviation increase in the estimated replacement risk (11.9 percentage points), leads to a five percentage point decline in the probability that the union selects the strike threat. This is the largest effect among the variables in the model, and confirms the shift in the composition of disputes predicted by the theory. Readers

\footnotetext{
${ }^{16} \mathrm{We}$ restrict the sample to disputes beginning after the decertification of PATCO.
} 


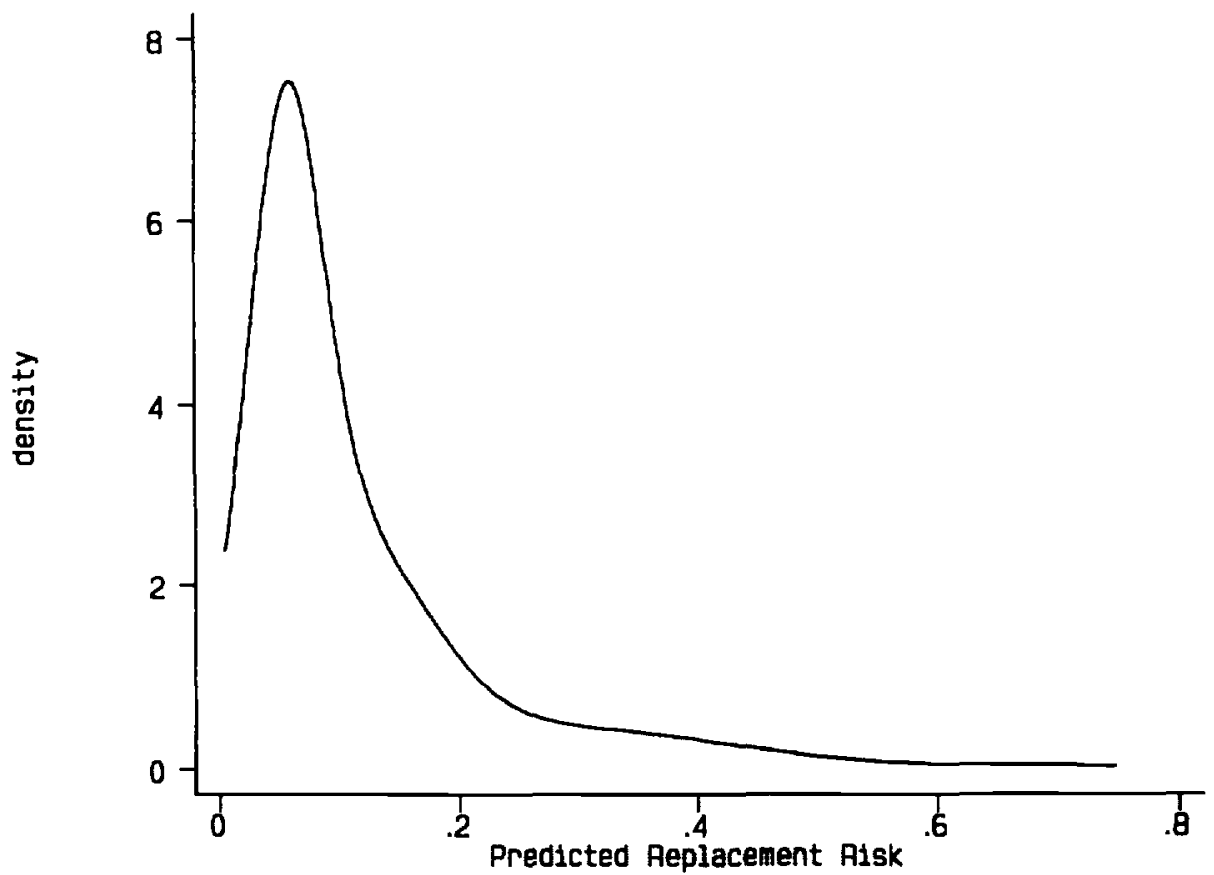

Figure 2.

Table 5: Summary Statistics on Predicted Replacement Risk

\begin{tabular}{ccccccccc}
\hline \hline Minimum & $10 \%$ & $25 \%$ & $50 \%$ & $75 \%$ & $90 \%$ & Maximum & Mean & Std Dev \\
\hline 0.007 & 0.021 & 0.048 & 0.078 & 0.150 & 0.272 & 0.746 & 0.119 & 0.119 \\
\hline
\end{tabular}


Table 6: Probit Model of the Probability of a Strike Given a Dispute

\begin{tabular}{lcc}
\hline \hline Variable & $(1)$ & $(2)$ \\
\hline Unemployment rate & -0.036 & -0.023 \\
& $(0.021)$ & $(0.021)$ \\
State employment residual & -0.035 & -0.048 \\
& $(0.021)$ & $(0.022)$ \\
State employment trend & 0.002 & -0.000 \\
& $(0.016)$ & $(0.016)$ \\
Industry employment residual & -0.020 & -0.020 \\
& $(0.017)$ & $(0.016)$ \\
Industry employment trend & -0.002 & 0.013 \\
& $(0.028)$ & $(0.019)$ \\
Union coverage density & 0.038 & 0.045 \\
& $(0.016)$ & $(0.016)$ \\
Union coverage concentration & -0.033 & -0.041 \\
\% change in real wage over prior contract & $(0.017)$ & $(0.017)$ \\
\% change in real wage over prior contract x & 0.010 & 0.013 \\
predicted replacement risk & $(0.016)$ & $(0.016)$ \\
Predicted replacement risk & & \\
\hline Number of observations & & -0.049 \\
\hline
\end{tabular}

Notes: Predicted replacement probabilities based on specification (1) of Table 4. Sample is restricted to 1982-1989. Coefficients represent the marginal effect of a one standard deviation change in a variable on the strike probability. Standard errors are given in parentheses, and for specification (2) have been adjusted for the two step estimation procedure used. 
interested in a discussion of results for the other determinants of the threat choice are referred to our earlier paper (Cramton and Tracy 1994).

Recall that a key prediction of the theory was a negative coefficient on the real wage variable in the dispute composition model. This coefficient estimate switches from negative to positive after 1981. If this sign switch is the result of the replacement risk in the 1980s, then we would expect to find a positive interaction between the real wage variable and the predicted replacement risk for the post 1981 period. The probit coefficient (standard error) on this interaction is $0.115(0.069)$. If the risk of replacement increased significantly after 1981, then this positive interaction would help to explain the sign reversal in our previous work.

The results of the threat-choice logit support the view that the risk of replacement shifts the composition of disputes toward holdouts, and explains in part the instability in a key coefficient. What remains to establish is that our estimate of the composition shift induced by replacement risk is economically significant. To this end, we use specification (2) of Table 6 to calculate the predicted probability that the union selects the strike threat given a labor dispute. We then set the estimated replacement risk to zero, and recalculate this conditional strike probability. We average these two sets of conditional strike probabilities by year. Table 7 reports these findings.

An important assumption used in this calculation is that the overall dispute incidence is unaffected by a ban on replacements. Dispute incidence depends essentially on the amount of uncertainty over private information variables. A ban on replacements may increase uncertainty, since the distribution of a firm's willingness to pay is no longer truncated by the firm's replacement option (Kennan and Wilson 1989). Hence, dispute incidence may increase with a ban on replacements.

However, if there are fixed costs associated with a strike, the parties have an added incentive to settle under the strike threat. Thus, any shift toward greater use of the strike threat induced by a ban on replacements may decrease dispute incidence. In light of these countervailing effects, assuming dispute incidence is unaffected by a ban on replacements seems a good place to start.

If a total ban on the use of replacement workers were in effect for the 1980s, our model estimates imply that the fraction of disputes involving a strike would have increased on average by 18 percentage points. The largest effect would have occurred in the years immediately following the PATCO demise. This translates into an increase of 3 percentage points in strike incidence, a 30 percent increase.

This sharp rise in the predicted strike incidence can be put into perspective by comparing it to estimates of the impact of the bans on replacements enacted in three Canadian provinces: Quebec in 
Table 7: Simulated Impact of a Ban on Replacement Workers

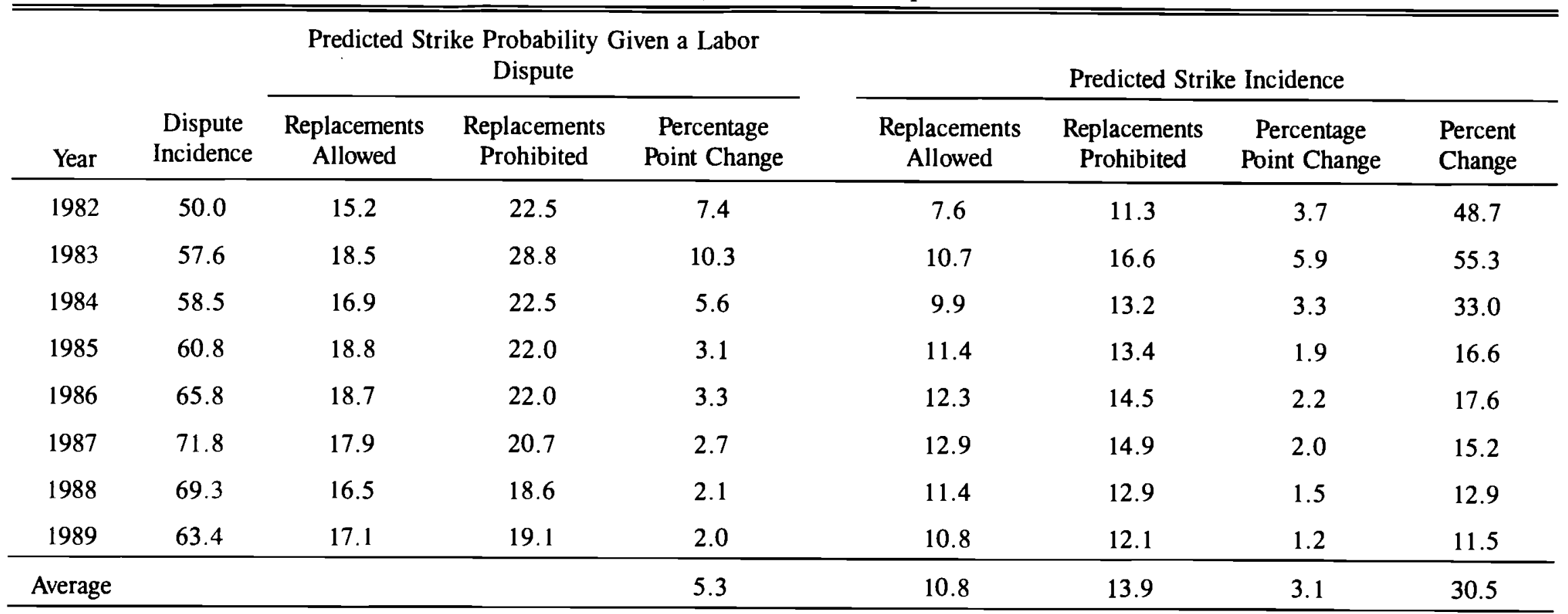

Notes: Predictions made using specification (1) of Table 4. Averages are weighted by relative number of disputes in each year. 
December 1977, and British Columbia and Ontario in December 1993. Cramton, Gunderson, and Tracy (1993) estimate the impact of these replacement bans as well as other labor policies on real wage settlements, strike incidence, and strike durations. This work extends the earlier work by Gunderson, Kervin, and Reid (1986) and Gunderson and Melino (1990). We use information on over 5,000 contracts negotiated between January 1967 and March 1993. The data indicate that banning replacements led to a 16 percentage point increase in the strike incidence (a doubling), a 40 percent (34 percent) increase in strike durations for large (all) strikes, and a 11 percent increase in the real wage. Given that the Canadian replacement bans also prohibit the firm from using transfers or management to maintain production, it is reasonable to expect that the effect on strike incidence to be stronger than what we find in the U.S..

\section{Conclusion}

The decline in U.S. strike activity in the 1980s represented a shift by unions from the strike threat to the holdout threat. This change in bargaining strategy could be a response to a heightened risk of replacements in the 1980s. To address this issue we estimate the determinants of the firm's decision to use replacements conditional on a strike. We find that firms are reluctant to use replacements the greater the level of job experience of their workers and the tighter the conditions are in the local labor market. We use this empirical model to estimate the replacement risk for each labor dispute in our sample occurring after 1981. We find that increases in the risk of replacement significantly reduce the likelihood that the union exercises the strike threat. We use this empirical model to estimate the effect of a complete ban on the use of replacements in the 1980s and conclude that strike incidence would have increased by one-third.

The current debate on amending the U.S. labor law to overturn or restrict the McKay Radio doctrine should be informed as to the likely efficiency and distributional effects. In this paper, we begin to address the efficiency issue by estimating the impact of a ban on replacements on the overall cost of negotiating labor contracts. Amending the current labor law to restrict the use of replacements will likely increase to a significant degree the overall negotiation costs through both more frequent and longer strikes. These costs have to be weighed against the benefits of reducing violence during strikes, and the consequences of shifting the distribution of rents toward labor unions through higher wage settlements. 


\section{References}

Bronars, Stephen, Donald Deere, and Joseph Tracy. "The Effect of Unions on Firm Behavior: An Empirical Analysis Using Firm-Level Data." Industrial Relations 33(October 1994): 426-451.

Cappelli, Peter. "Concession Bargaining and the National Economy." In Proceedings of the ThirtyFifth Annual Meeting, 362-71. Madison, WI: Industrial Relations Research Association, 1982.

Cramton, Peter, Morley Gunderson, and Joseph Tracy. "The Effect of Collective Bargaining Legislation on Strikes and Wages." Working Paper. 1993.

Cramton, Peter C., and Joseph S. Tracy. "The Determinants of U.S. Labor Disputes." Journal of Labor Economics 12(April 1994): 180-209.

-.--.- "Strikes and Holdouts in Wage Bargaining: Theory and Data." Americal Economic Review 82(March 1992): 100-121.

Farber, Henry S., and Alan B. Krueger. "Union Membership in the United States: The Decline Continues." Working Paper \#306. Industrial Relations Section, Princeton University, August, 1992.

Freedman, Audrey. The New Look in Wage Policy and Employee Relations. New York: The Conference Board, Research Report, 1985.

-----. "A Fundamental Change in Wage Bargaining." Challenge 25(July-August 1982): 14-17.

Gramm, Cynthia. "Employers' Decision to Operate During Strikes: Consequences and Policy Implications." In Employee Rights in a Changing Economy: The Issue of Replacement Workers, edited by William Spriggs. Washington, DC: Economic Policy Institute, 1991.

Gramm, Cynthia L., and John F. Schnell. "The Effect of Using Permanent Striker Replacements on Operating Ability, Employment Security, and Bargaining Outcomes." Working Paper, University of Alabama - Huntsville. 1993.

Gunderson, Morley, John Kervin, and Frank Reid. "Logit Estimates of Strike Incidence from Canadian Contract Data." Journal of Labor Economics 4(April 1989): 257-276.

Gunderson, Morley, and Angelo Melino. "The Effects of Public Policy on Strike Duration." Journal of Labor Economics 8 (1990): 296-316.

Industrial Union Department. The Inside Game: Winning with Workplace Strategies. Washington, DC: AFL-CIO, 1986.

Mitchell, Daniel. "Recent Union Contract Concessions." In Brookings Papers on Economic Activity, 165-204. Washington, DC: Brookings Institution, 1982. 
------. "The 1982 Union Wage Concessions: A Turning Point For Collective Bargaining?" California Management Review 25(Summer 1983): 78-92.

Olson, Craig. "The Use of Strike Replacements in Labor Disputes: Evidence from the 1880s to the 1980s." Working Paper. Industrial Relations Section, Princeton University, 1991.

U.S. General Accounting Office. "Labor-Management Relations: Strikes and the Use of Pemanent Strike Replacements in the 1970s and 1980s." Report to Congressional Requestors, GAO/HRD91-2. 1991. 